DOI 10.37882/2500-3682.2022.01.06

\title{
ОБРАЗЫ КИТАЙЦЕВ В РУССКОЙ ЛИТЕРАТУРЕ ДАЛЬНЕГО ВОСТОКА НАЧАЛА ХХ ВЕКА КАК ОТРАЖЕНИЕ КУЛЬТУРНЫХ ВЗАИМОДЕЙСТВИЙ
}

\section{IMAGES OF THE CHINESE IN RUSSIAN LITERATURE OF THE FAR EAST AT THE BEGINNING OF THE TWENTIETH CENTURY AS A REFLECTION OF CULTURAL INTERACTIONS}

Meng Fanhong

Summary: The article analyzes the reflection of the presence of Chinese in the Far East in Russian literature of the early twentieth century from the point of view of cultural interactions between residents of Russia and Chinese immigrants. It is noted that in order to understand the literature of this period, it is necessary to study the history of Chinese immigration. The Chinese first appeared in the Russian Far East in the middle of the 19th century. Since then, the problem of Chinese immigration in the Far East has occupied the consciousness of Russians and appears in the writings of a number of famous travelers, ethnographers, public figures, as well as in works of fiction. The image of the Chinese, embodied in the Russian literature of this period, reflects the peculiarities of the integration of the Chinese who lived in the Russian Far East into the local society. In literature, in particular, in the verses of $\mathrm{V}$. Mart, the image of the Chinese is created as an eternal worker, performing low-skilled work, often a smoker of opium. Such images of the Chinese recreate the realities: both the fears of local residents before the «invasion» of the Chinese population, and the unwillingness of the Chinese themselves to assimilate, to be included in Russian life and culture.

Keywords: Far East, Russia, China, emigration, immigration, the image of the Chinese, literature, culture.

\section{Введение}

$\Pi$ роблема восприятия Китая и китайцев в русской литературе и культуре становится предметом анализа многих исследователей, специалистов различных гуманитарных дисциплин в связи с тем, что связи между Россий и Китаем с каждым годом становится всё более тесными и разнообразными. А.А. Забияко и Е.В. Сенина выявляют «противоположные тенденции, влияющие на восприятие Китая и китайцев», и отмечают,
Мэн Фаньхун

Профрессор, Хэйхэский университет, КНР, провинция Хэйлунцзян, г. Хэйхэ

479884839@q9.com

Аннотация: В статье анализируется отражение присутствия китайцев на Дальнем Востоке в русской литературе начала XX века с точки зрения культурных взаимодействий между жителями России и китайскими иммигрантами. Отмечается, что для понимания литературы этого периода необходимо изучить историю китайской иммиграции. Китайцы впервые появились на Дальнем Востоке России в середине XIX века. С тех пор проблема китайской иммиграции на Дальнем Востоке занимает сознание россиян и появляется в трудах ряда известных путешественников, краеведов, общественных деятелей, а также в произведениях художественной литературы. Образ китайца, воплощенный в русской литературе этого периода, отражает особенности интеграции китайцев, проживавших на Дальнем Востоке России, в местное общество. В литературе, в частности, В стихах В. Марта, создаётся образ китайца как вечного труженика, выполняющего низкоквалифицированную работу, нередко курильщика опиума. Подобные образы китайцев воссоздают реалии: как опасения местных жителей перед «нашествием» китайского населения, так и нежелание самих китайцев ассимилироваться, включаться в русскую жизнь и культуру.

Ключевые слова: Дальний Восток, Россия, Китай, эмиграция, иммиграция, образ китайца, литература, культура.

что в русской литературе в течение XX века встречались как негативная, так и позитивная трактовки образа Китая [Забияко, 2018, 212]. М.Н. Крылова также отмечает различные коннотации китайских образов, но в то же время пишет: «Начиная с XVIII века, Китай служил для русской аристократии символом экзотического и поэтому манящего Востока» [Крылова, 2016, 227]. Е.В. Сенина в диссертационном исследовании отмечает, что именно в 1920-х годах образ Китая и китайцев перестаёт быть в российском сознании «условным, стереотипно-схематичным»

Данная статья является результатом научно-исследовательского проекта 2020 г. Ключевые исследовательские проекты экономического и социального развития в провинции Хэйлунцзян «Образ Китая в русской литературе и документах Дальнего Востока 1900-2000 гг.». Номер проекта: 20531 
[Сенина, 2018, 11]. Д.А. Владимирова считает нужным подчеркнуть культурную обособленность китайских иммигрантов в России: «Китайцы, которые жили на российской территории, неохотно подчинялись российским законам, жили замкнуто, скрывая свою жизнь от постороннего взора» [Владимирова, 2005, 15]. Чэн Хун, Ван Сюй концентрируют внимание на причинах китайской эмиграции и делают вывод, что «основой для привлечения большого количества китайцев в Россию явились чисто экономические, а не политические факторы» [Чэн Хун, 2021, 109]. Я. Тань и Ян Чжан выявляют, что «основную часть переселенцев составляли чернорабочие и малограмотные крестьяне» [Тань, 2021, 64]. Эмиграция китайского населения на Дальний Восток стала особенно интенсивной в 1920-1930-х годах. Интенсивность эмиграции была связана с демографическим дисбалансом между Китаем и Дальним Востоком [Дудченко, 2002], а также с политическими и экономическими причинами.

Исследователи считают, что уже в этот период на Дальнем Востоке были созданы условия для налаживания дружественных отношений между русским и китайским народами. Так, Н.П. Рябченко пишет: «В годы Первой мировой войны сотни тысяч китайцев прибыли в Россию на работу. Это дало возможность русским и китайцам лучше узнать друг друга и понять, что между ними нет психологического барьера, а культурные различия хотя и велики, но преодолимы» [Рябченко, 2009, 10]. На Дальнем Востоке в результате взаимодействия между населением России и эмигрантами из Китая сложились условия для культурных связей и даже для формирования общего культурного пространства, что не могло не отразиться на развитии литературы.

Цель статьи - провести анализ того, как в русской литературе 1920-1930-х годов отразились образы Китая и китайцев, и выявить зависимость данных образов от культурных факторов, от того, каким образом включались в жизнь России иммигранты из Китая.

\section{Типы ^итературных текстов, фиксируюших образы китайшев}

Существует три типа произведений литературы, которые фиксируют и описывают образы китайцев на Дальнем Востоке России.

Первый тип - путевые заметки и очерки путешественников, краеведов и географов. Например, В.В. Граве «Китайцы, корейцы и японцы в Приамурье» (1912), В.К. Арсеньев «Китайцы в Уссурийском крае: Очерк историко-этнографический» (1914), Н.М. Пржевальский «Путешествие в Уссурийском крае. 1867-1869» (1949), Се Хуайдань «Следы прожитых лет. Воспоминания студент- ки Московского университета Сунь Ятсена» (1991), Лю Цзяньминь «Организация как преемник клановой ассоциации» (1993), Ши Чжэ «Моя жизнь: воспоминания Ши Чжэ» (2001) и др.

Вторая категория - романы, очерки, стихи, биографии, песни и другие произведения писателей, поэтов и этнографов. Например, Д.И. Шрейдер «Наш Дальний Восток» (1897), М.А. Булгаков «Китайская история» (1923), П.А. Северный «Фарфоровый китаец качает головой» (1937), Ли Юнчан «О китайских рабочих в России в период новой истории Китая» (1987), Ван Цзин «Китайские рабочие в России и экономическое развитие на Дальнем Востоке России» (1996), Нин Яньхун «Столетняя история китайских мигрантов» (2019) и др.

Третья категория - это мемуары, очерки, письма, правительственные документы, официальные опубликованные отчеты, руководства и другие источники, созданные учеными, писателями, официальными лицами. Например, Г.Е. Грум-Гржимайло «Описание Амурской области» (1894), А.В. Даттан «Исторический очерк развития приамурской торговли» (1897), П.Ф. Утербергер «Приморская область 1856-1898 гг.» (1900), А.Е. Маковкин «1-й Нерчинский полк Забайкальского казачьего войска» (1907), С.В. Витковская «Кругом земли» (1915), И.Я. Коростовец «Россия на Дальнем Востоке» (1922), Сюй Цзунлян «Краткий отчет о Хэйлунцзяне» (1985), Сюй Ванминь «Восточно-китайские бизнесмены на Дальнем Востоке России» (1993) и др.

Источники всех данных категорий в течение многих десятилетий помогают формировать образы китайцев, которые входят в русскую культуру и постепенно становятся важной её частью.

\section{Отражкение образов китайшев в художественной литературе}

В период эмиграции китайцев на Дальний Восток в 1920-1930-х годах большинство из них не понимали местного языка и были материально необеспеченными. Как правило, они принадлежали к низам общества, были пекарями, мясниками, поварами, портными, сапожниками, переплетчиками, строителями, золотоискателями и т.д. Соответствующие сцены из жизни и работы китайских рабочих вскоре начали появляться в русской литературе.

Носильщиков (нощильник) также часто называли кули, а местные жители в просторечии именовали «каули» или «каваль». Во Владивостоке носильщики считались городским наземным транспортным средством, и, согласно правилам городского уличного движения, 
эти «транспортные средства» должны были двигаться по правой стороне дороги, а не ходить по тротуару, поскольку они несли на спине тяжелые предметы.

В 1891 г. только в Амурском пароходстве было занято 506 китайских рабочих, что составляло 30 \% от общего числа рабочих. Каждый год, когда начинался Праздник Весны, в этот залив из Маньчжурии приходило много парусных лодок грузоподъемностью до 10 т. Здесь временами было пришвартовано 500-800 черных парусов и плоскодонных лодок с национальными флагами. Товары, перевозимые на данных судах, - это соевое масло, спиртные напитки, табак, чай, женьшень, мех и другие. Китайские рабочие обменивали эти товары на русские водоросли, трепанги и гребешки. Перед прибытием парусника у пристани собирались заграничные китайцы и местные жители; это было похоже на большой, шумный базар, где стороны торговались и обменивались товарами [Чжао Чуньфан].

Во Владивостоке китайских судоходных рабочих называли «юли-юли» - производное от русского глагола «юлить» в значении «трясти». В стихотворении «На Амурском заливе» поэт Венедикт Март создал образ китайского лодочника, покачивающегося и поющего среди синих волн залива.

«Юлит» веслом китаец желтолицый.

Легко скользит широкая шаланда

По тихой глади синих вод залива.

Пред ним Востока Дальнего столица:

Владивосток за дымкою тумана,

На склонах гор застыл он горделиво.

Как всплески под кормою, монотонно,

Поет тягуче за веслом китаец

Про Хай-шин-вей - «трепангов град великий».

Над ним в далях небес светло-зеленых

Полоски алые в томленьи тают

И звезды робко открывают лики [Март, 1922, 6].

Большой популярностью пользовались на Дальнем Востоке местные китайские торговцы, которые в кратчайшие сроки доставляли еду в дома горожан, что делало жизнь более удобной. Нин Яньхун пишет в монографии, что китайские купцы в Сяобэйтуне Благовещенска открыли мастерские по производству тофу, вермишели, а также бойни и т. д. Был и более крупный бизнес, созданный Цзян Жунцаем, уроженцем уезда Хуансянь в Шаньдуне - Цюаньсин Фу, в основном занимавшимся нефтью, производством соли, соусов, уксуса и продуктов повседневного спроса. Была закусочная, открытая Ян Кунхэ и другими жителями Хэбэя; гостиница, открытая Чен Байсуй, уроженцем округа Хуансянь, Шаньдун, а также баня, парикмахерская, магазины кожаной обуви и одежды. Существовали также небольшие ремесленники, ко- торые ходили по улицам и переулкам с инструментами на спине. Они занимались резкой стекла для инкрустации дверей и окон, сваркой, ремонтом кожаной обуви, управлением лошадьми и телегами для доставки воды и т.д. Кроме того, был рынок труда, и многие плотники, каменщики и другие рабочие собирались там каждый день в ожидании приема на работу [Нин Яньхун, 2019, 125].

Китайские мигранты-рабочие часто сохраняли свои пристрастия и дурные привычки, поэтому в восприятии русских жителей Дальнего Востока китаец - это прежде всего курильщик, живущий сегодняшним днём.

В 1916 году Венедикт Март описал приют для курильщиков опиума и его опьяняющую атмосферу в своем стихотворении «В курильне»:

Зорко и пристально взглядом стеклянным

Смотрит курильщик на шкуру тигрицы -

Некогда хищного зверя Амура.

Чтобы отдаться объятиям пьяным,

Женщина с юношей ею прикрылись.

Смотрит курильщик, как движется шкура.

Странны, познавшему опия сладость,

Страсти животные к женщинам низким,

Страсти, мрачащие души - не мудрых.

Тихо в курильне и душно от чада,

Редко шипение лампы при вспышке,

Вздохи... чуть слышится шепот под шкурой.

Тени и блики на желтых циновках.

Дым поднимается темным туманом.

Курят в молчании желтые люди.

Мак, точно маг-чаротворец багровый,

Явь затемняет обманом дурмана,

Чадные грезы тревожит и будит [Март, 1922, 10].

Согласно отчету Чжао Чуньфана о приобретении и сборе средств на границе, золотодобывающая промышленность на Дальнем Востоке - это отрасль, в которой больше всего работали китайские рабочие. С середины 1910-х годов сотни китайцев отправились работать на золотые прииски на Дальнем Востоке России. С развитием российской золотодобывающей промышленности количество китайских рабочих увеличилось и составляло значительную долю. На золотых приисках вдоль рек Хэйлунцзян и Уссури в России тысячи китайских рабочих, которые едут в Россию, были заняты добычей золота, составляя подавляющее большинство золотодобытчиков. В течение трех лет правления Сюаньтун (1911 г.) вследствие плохого управления китайским золотым рудником Мохэ, где чиновники и люди боролись за прибыль, людям стало невыгодно заниматься золотодобычей в Китае, поэтому многие китайцы предпочли перебраться для этого в Россию [Чжао Чуньфан].

Энтузиазм китайского народа по поводу добычи зо- 
лота был велик. Фактически, по состоянию на 1908 год более 15000 китайских золотодобытчиков работали на более чем 140 золотодобывающих предприятиях, расположенных вдоль реки Амур. Золотоискатели обычно намеревались скопить немного золота и вернуться в Китай.

\section{Аспекты культурного взаимодействия китайшев и русских на $\triangle$ альнем Востоке}

Хотя китайцы пришли на Дальний Восток вследствие нехватки рабочей силы и использовались здесь для экономического развития, они, естественно, участвовали во многих сферах городской жизни Дальнего Востока. Неизбежным стало начало приграничного культурного обмена с местными жителями. Необходимо выявить характеристики этого вида приграничного общения. Отметим, что китайцы обычно предпочитали держаться обособленно от русской культуры. Их отношение к русской культуре и возможной ассимиляции базировалось на следующих трех убеждениях.

1. Китайцы обладают хорошими навыками ведения бизнеса.

«Китайцы рождены, чтобы быть купцами» - таково было единодушное мнение россиян, которые полагали, что наиболее важной экономической деятельностью китайцев является ведение бизнеса. Фактически эмигранты из Китая захватили все экономические сферы Дальнего Востока и начали влиять на образ жизни в регионе. Китайские товары были намного дешевле и быстрее доходили до потребителей, вследствие чего жители Дальнего Востока вскоре высоко оценили китайских бизнесменов, способных максимально эффективно использовать все благоприятные условия для увеличения своего дохода. Большинство китайских бизнесменов были известны своей энергией, агрессивностью, ловкостью, опытом ведения бизнеса, гибкостью и тактичностью в деловой сфере, что гарантировало им финансовый успех. М.В. Ходяков отмечает, что Россия в этот период даже начала «процесс выработки законодательных мер, направленных на защиту дальневосточной экономики от дешевого труда китайцев и корейцев» [Ходяков, 2019, 78].

2. Необходимо держаться подальше от мейнстрима российской жизни.

Русские считают, что китайские традиции и обычаи не сочетаются с русской жизнью, особенно в повседневном существовании. Так, китайцы живут в своих поселениях, обычно в отдельной части города, со своими обычаями, своими магазинами, ванными, парикмахерскими, театрами и местами для общественных встреч, тавернами, игорными залами, барами и т.д. При этом жизненные потребности китайцев чрезвычайно скромны, они довольствуются очень немногим, привыкли сводить свои нужды к самому низкому уровню, который абсолютно невозможен для европейцев. Китайцы очень бережливы, мало тратят на одежду и развлечения и почти не употребляют алкогольные напитки.

\section{3. Важно поддерживать китайскую культуру.}

С точки зрения русских, несмотря на приток все большего числа китайцев в Россию, китайские иммигранты не разрывали связи с родиной. Во-первых, сохранялись их родной язык, национальная еда, традиционные праздники, обряды и национальные костюмы, во-вторых, изготавливались китайские вывески в общественных местах. Например, китайские магазины, особенно небольшие и средние, как правило, были полны национального колорита; возле входа вешали красочную вывеску на холсте, нарисованную китайскими иероглифами. Такой образ жизни обеспечивал максимальный психологический комфорт. Дело в том, что китайцы не стремились селиться в России, им было свойственно сильное желание вернуться домой, они считали, что пребывание в России носит временный характер. Русских очень удивляло, что у китайцев не было в России жен и семей, что они не строили для себя постоянных домов. Семья должна была оставаться в Китае, на родине, а единственное, к чему стремился китаец, - это к тому, чтобы скопить немного денег или золота, а затем вернуться в страну.

Данные факторы, несомненно, влияли на восприятие жителями Дальнего Востока китайских иммигрантов и воздействовали на то, что в литературе того периода китаец - это необычный человек, чужак, совершенно не похожий на русских людей.

\section{Зак^ючение}

С 1870 по 1937 год китайцы составляли основной массив мигрантов на Дальнем Востоке России. Хотя они и стали рабочей силой, от которой зависело дальневосточное общество и местные жители, их все же неизбежно считали «русскими чужаками» и даже «второсортными жителями» Дальнего Востока. Китайцы страдали от дискриминации, поскольку на Дальнем Востоке их называли «манзы» (варвары), «ходя» (на побегушках), «китаюза» (китайцы) и «купеза» (разносчики). Эти термины выражали отношение россиян к китайским иммигрантам, порой презрение и высокомерие. С одной стороны, Дальний Восток полностью зависел от китайской рабочей силы, товаров и услуг, с другой - он боялся этой «желтой опасности» и считал, что китайские иммигранты гораздо страшнее армий и военных кораблей. Все это 
вкупе составляло противоречивую и сложную картину зависимости России от китайских иммигрантов и одновременно неприязни к ним. Поэтому такие прекрасные качества китайцев, как трудолюбие и взаимопомощь, а также умение вести дела, могли получить от россиян негативную эмоциональную окраску. Китайские иммигранты рассматривались как потенциальная угроза и чрезвычайно опасные конкуренты на Дальнем Востоке. В то же время закрытость групп китайских иммигрантов и их сопротивление ассимиляции также являлись значимыми характеристиками дальневосточных китайцев, препятствующими их интеграции в местное общество.

Всё это не могло не отразиться в литературе и формировало образ китайца как постоянно работающего человека, принадлежавшего к низшим слоям общества, а также курильщика опиума, в целом - как человека чужого, значительно отличающегося в культурном плане.

\section{ЛИТЕРАТУРА}

1. Владимирова Д.А. Проблемы этнокультурного взаимодействия и взаимовосприятия китайцев и русских на российском Дальнем Востоке и Северо-Востоке Китая: автореф. дис. ... канд. истор. наук. Владивосток, 2005. - 20 с.

2. Дудченко Г.Б. Китай и Дальний Восток России: к вопросу о демографическом дисбалансе // Вестник Евразии. 2002. № 3. С. 142-149.

3. Забияко А.А., Сенина Е.В. Образ восприятия Китая и китайцев в русской дореволюционной литературе и публицистике XX в. // Социальные и гуманитарные науки на Дальнем Востоке. 2018. № 4. С. 212-219.

4. Крылова М.Н. Символика Китая в современной русской литературе // Критика и семиотика. 2016. № 1. С. 227-235.

5. Март В. Песенцы: Китайские этюды. Стихи. Харбин: Кооператив, 1922. 14 с.

6. Нин Яньхун. Столетняя история китайских мигрантов. Гуанчжоу: Изд-во Цзинаньского ун-та, 2019. 364 с.

7. Рябченко Н.П. Дружественные связи России и Китая на Дальнем Востоке: история и современность // Ойкумена. Регионоведческие исследования. 2009. № 3 (10). С. 9-16.

8. Сенина Е.В. Образы взаимного восприятия русских и китайцев в русской и китайской литературе и публицистике первой половины XX в.: дис. ... канд. филол. наук. Благовещенск, 2018. 246 с.

9. Тань Я., Чжан Ян. Исследование исторических данных эмиграции из Китая 1920-1930 гг. // Исторический бюллетень. 2021. Т. 4. № 2. С. 64-67.

10. Ходяков М.В. Российское законодательство начала XX века об использовании желтого труда в экономике Дальнего Востока // Вестник Томского государственного университета. История. 2019. № 60. С. 78-83.

11. Чжао Чуньфан. Отчет о собрании пограничных дел // Айгуньский Районный архив. Ф.: Айгуньские архивы. Оп.: Иностранные дела. Д. 13.

12. Чэн Хун, Ван Сюй. К вопросу о китайской эмиграции в Россию (середина XIX - начало XX в.) // Вопросы истории. 2021. № 1. С. 109-120. 